\title{
Extraction of human genomic DNA from whole blood using a magnetic microsphere method
}

\author{
This article was published in the following Dove Press journal: \\ International Journal of Nanomedicine \\ 8 August 2014 \\ Number of times this article has been viewed
}

\author{
Rui Gong' \\ Shengying $\mathrm{Li}^{2}$ \\ 'Pharmaceutical Department, The \\ Second Hospital of Tianjin Medical \\ University, ${ }^{2}$ Clinical Laboratory, \\ Tianjin Children's Hospital, Tianjin, \\ People's Republic of China
}

Correspondence: Rui Gong Pharmaceutical Department, The Second Hospital of Tianjin Medical University, Pingjiang Road 23, Hexi District, Tianjin City, Tianjin, People's Republic of China 3002II

Email li_shy2000@163.com

\begin{abstract}
With the rapid development of molecular biology and the life sciences, magnetic extraction is a simple, automatic, and highly efficient method for separating biological molecules, performing immunoassays, and other applications. Human blood is an ideal source of human genomic DNA. Extracting genomic DNA by traditional methods is time-consuming, and phenol and chloroform are toxic reagents that endanger health. Therefore, it is necessary to find a more convenient and efficient method for obtaining human genomic DNA. In this study, we developed urea-formaldehyde resin magnetic microspheres and magnetic silica microspheres for extraction of human genomic DNA. First, a magnetic microsphere suspension was prepared and used to extract genomic DNA from fresh whole blood, frozen blood, dried blood, and trace blood. Second, DNA content and purity were measured by agarose electrophoresis and ultraviolet spectrophotometry. The human genomic DNA extracted from whole blood was then subjected to polymerase chain reaction analysis to further confirm its quality. The results of this study lay a good foundation for future research and development of a high-throughput and rapid extraction method for extracting genomic DNA from various types of blood samples.
\end{abstract}

Keywords: magnetic separation, bioseparation, resin magnetic microspheres, human genomic DNA, extraction

\section{Introduction}

With the rapid development of molecular biology and the life sciences, magnetic extraction is a simple, automatic, and highly efficient method for separation of biological molecules, performing immunoassays, and other applications. Blood is an ideal source of human genomic DNA. ${ }^{1-3}$

Being able to prepare human genomic DNA from whole blood with high purity and in sufficient quantities from fresh trace blood is important both in basic science research and in the clinical setting. However, extracting genomic DNA by traditional methods is a time-consuming process, and phenol and chloroform are toxic reagents that endanger health. ${ }^{2-6}$ Further, traditional methods, such as phenol extraction, isopropanol precipitation, the formamide lysate method, nonorganic solvent extraction, and glass particle adsorption, have been found to be ineffective for extracting genomic DNA from trace, dried, and frozen blood. Therefore, it is necessary to find a more convenient and efficient method for obtaining human genomic DNA. ${ }^{7-10}$

In this work, we developed urea-formaldehyde resin magnetic microspheres and magnetic silica microspheres to extract human genomic DNA. This method lays a good foundation for future research and development of a high-throughput and is a rapid method for extracting genomic DNA. 


\section{Materials and methods Materials}

The calf thymus used in this study was obtained from Hongguang Farm (Beichen District, Tianjin, People's Republic of China). A urea-formaldehyde resin magnetic ball was sourced from the SiLe Chromatography Technology Development Center (Tianjin, People's Republic of China). Dried, fresh, and frozen blood samples were obtained from the Second Hospital of Medical University. For the experiments involving human subjects, approval was obtained from the institutional review board of Tianjin Medical University. Informed consent was obtained in accordance with the tenets of the Declaration of Helsinki. Collection and preparation of fresh blood followed procedures described elsewhere. ${ }^{11}$

\section{Preparation of magnetic microsphere suspension}

Urea-formaldehyde resin magnetic microspheres were dispersed in phosphate-buffered saline $(137 \mathrm{mmol} / \mathrm{L}$ $\mathrm{NaCl}, 2.7 \mathrm{mmol} / \mathrm{L} \mathrm{KCl}, 10 \mathrm{mmol} / \mathrm{L} \mathrm{Na}_{2} \mathrm{HPO}_{4}, 2 \mathrm{mmol} / \mathrm{L}$ $\mathrm{KH}_{2} \mathrm{PO}_{4}$ ) at a final concentration of $0.01 \mathrm{~g} / \mathrm{mL}$. Under magnetic field conditions, $1.0 \mathrm{~mL}$ of the prepared magnetic microsphere suspension was mixed and washed twice with phosphate-buffered saline. The supernatant was discarded and the washed urea-formaldehyde resin magnetic microspheres were harvested. Next, $10 \mathrm{mg}$ of the prepared urea-formaldehyde resin magnetic microspheres were mixed with $1 \mathrm{~mL}$ of polyethylene glycol (PEG)-8000 sorbent for 3 minutes at room temperature. Finally, urea-formaldehyde resin magnetic microspheres were produced ready for use.

\section{Extraction of human genomic DNA}

A flow chart of the DNA extraction process is shown in Figure 1. First, $200 \mu \mathrm{L}$ of lysis buffer $(20 \mathrm{mM}$ Tris, $2 \mathrm{mM}$ ethylene glycol tetraacetic acid, 1\% NP-40, $0.2 \mathrm{mM}$ E64, $1 \mathrm{mM}$ phenylmethylsulfonyl fluoride, $0.08 \mathrm{U} / \mathrm{mL}$ aprotinin, and $2 \%$ Triton $\mathrm{X}-100, \mathrm{pH} 7.4$ ) with high salinity were added to the precipitate. The mixture was mixed thoroughly, left to stand for 10 minutes, and then centrifuged at 4,000 rpm for 5 minutes. Next, $200 \mu \mathrm{L}$ of white cell lysis buffer solution (STE, $40 \mathrm{mmol} / \mathrm{L}$ Tris- $\mathrm{HCl}, 40 \mathrm{mmol} / \mathrm{L}$ ethylenediaminetetraacetic acid disodium salt, and $0.8 \mathrm{~mol} / \mathrm{L}$ guanidinium isothiocyanate, $\mathrm{pH}$ 6.7) was added in the mixture, which was then vibrated evenly and strongly. Proteinase K $100 \mu \mathrm{g} / \mathrm{mL}$ was added to the mixture, followed by incubation in a water bath at $56^{\circ} \mathrm{C}$ for 3 hours, with reverse-mixing every 30 minutes. Half a milligram of magnetic microspheres was

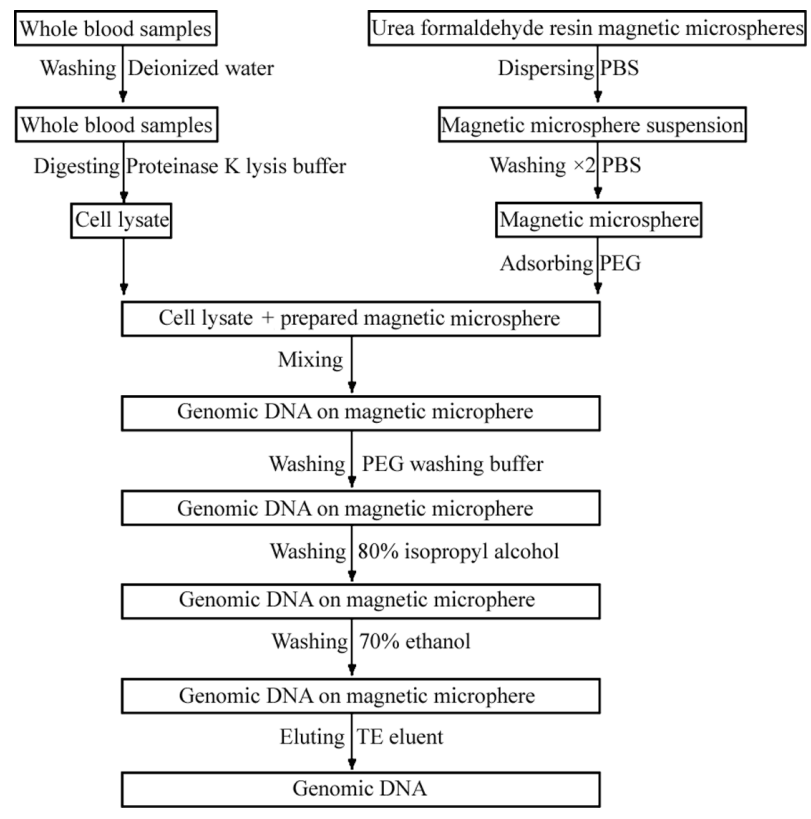

Figure I Flow chart of DNA extraction processes. Abbreviations: PBS, phosphate buffer solution; PEG, polyethylene glycol.

removed, the adsorbent PEG was added, and the mixture was then incubated for a further 3 minutes. The pretreated magnetic microspheres were added to the prepared liquid mixture. Absorption was allowed for 10 minutes followed by magnetic separation, after which $400 \mu \mathrm{L}$ of PEG-8000 was used to wash the beads twice and the supernatant was discarded; the same procedure was repeated using $400 \mu \mathrm{L}$ of $80 \%$ isopropyl alcohol and $400 \mu \mathrm{L}$ of $75 \%$ ethanol. The beads were then dried in the ventilation cupboard at room temperature for about 30 minutes. TE buffer corresponding to dried blood $(50 \mu \mathrm{L}, 100 \mu \mathrm{L}, 200 \mu \mathrm{L})$ was used to elute the beads. After magnetic separation, the TE buffer containing the DNA was transferred to a fresh Eppendorf tube for further use. The genomic DNA extracted from human blood was subjected to agarose gel electrophoresis to detect its molecular size and integrity and to roughly estimate the DNA content. The ultraviolet absorption method was used to further measure the DNA purity and content.

\section{Detection of DNA by agarose gel electrophoresis}

The extracted DNA was analyzed by DNA agarose gel electrophoresis, as described previously.

\section{Determination of DNA content by ultraviolet spectrophotometry}

The content and purity of the extracted human whole blood genomic DNA was determined by ultraviolet 
spectrophotometry. Briefly, the ultraviolet absorption peak at $260 \mathrm{~nm}$ was detected. The OD values of the A260 and A280 in each extracted genomic DNA sample were measured. When the OD260 was 1 , the concentration of double-stranded DNA in a sample of genomic DNA was $50 \mu \mathrm{g} / \mathrm{mL}$.

\section{PCR amplification}

The quality of genomic DNA extracted by the magnetic microsphere method was investigated further by polymerase chain reaction (PCR) amplification. PCR primers of the human $\beta$-actin gene (ie, P29074 and P29075) were used. The sequence for the upstream primer (P29074) was 5'-ATC ATG TTT GAG ACC TTC AA-3' and for the downstream primer (P29075) was 5'-CAT CTC TTG CTC GAA GTC CA-3'. The length of the PCR product was approximately 300 base pairs.

The PCR parameters were as follows: volume $30 \mu \mathrm{L}$, $5 \mu \mathrm{L}$ of $10 \times$ PCR buffer, $10 \mu \mathrm{L}$ of dNTP $(10 \mathrm{mmol} / \mathrm{L}), 1 \mu \mathrm{L}$ of P29074 primer (12.5 nmol/L), $1 \mu \mathrm{L}$ of P29075 primer (12.5 nmol/L), $1 \mu \mathrm{L}$ of dimethylsulfoxide, $1 \mu \mathrm{L}$ of Pfu Taq polymerase, $5 \mu \mathrm{L}$ of human genomic DNA template, and $6 \mu \mathrm{L}$ of water. The PCR reaction procedures were as follows: $94^{\circ} \mathrm{C}$, predenaturation for 5 minutes, $94^{\circ} \mathrm{C}, 30$ seconds, $55^{\circ} \mathrm{C}, 30$ seconds, $72^{\circ} \mathrm{C}, 60$ seconds, 35 cycles, $72^{\circ} \mathrm{C}$, extending for 5 minutes. The products of PCR were analyzed by agarose gel electrophoresis.

\section{Results}

\section{Genomic DNA extracted from various blood samples by different methods}

The quantity and purity of DNA extracted by the various methods including the different buffers were analyzed and compared in the present study. All extraction methods could effectively eliminate interference from fresh hemoglobin and impurities in the blood samples, and the purity reached more than 1.7. The amount of DNA extracted was relatively low using the magnetic microsphere method and Triton-Tris- $\mathrm{HCl}$ solution (1\% Triton X-100, 2 mmol/L Tris-HCl, pH 8.3) as the buffer, but its purity was very high. In contrast, both the quantity and purity of DNA extracted by the classic method of ammonium chloride hemolysin were high, but the advantages of high yield of magnetic microspheres failed to reflect. The highest DNA yield was from fresh blood treated with deionized water; its purity was close to 1.8 , so it met the experimental requirements (Table 1). Fresh blood pretreated with deionized water was used in subsequent experiments.
Table I Genomic DNA from blood with different treatment methods

\begin{tabular}{lll}
\hline & $\begin{array}{l}\text { DNA purity } \\
\text { (A260/A280) }\end{array}$ & $\begin{array}{l}\text { DNA content } \\
(\mathbf{2 0 0} \mu \mathrm{L})\end{array}$ \\
\hline $\begin{array}{l}\text { Ammonium chloride } \\
\text { hemolysin }(\mathrm{n}=20)\end{array}$ & $1.73 \pm 0.16$ & $4.30 \pm 0.69 \mu \mathrm{g}$ \\
TT solution $(\mathrm{n}=10)$ & $1.81 \pm 0.59$ & $3.25 \pm 0.72 \mu \mathrm{g}$ \\
Deionized water $(\mathrm{n}=10)$ & $1.78 \pm 0.39$ & $7.21 \pm 0.84 \mu \mathrm{g}$ \\
\hline
\end{tabular}

Abbreviation: TT solution, Triton-Tris- $\mathrm{HCl}$ solution.

\section{Comparison of protease $\mathrm{K}$ and $\mathrm{Nal}$ extraction methods}

The OD value for DNA extracted using the NaI method was high when measured by ultraviolet absorption. According to the calculation results of the DNA content by the confirmed equation, the obtained DNA was above $15 \mu \mathrm{g}$, which is more than the normal yield of human genomic DNA. Gel electrophoresis showed that the DNA content harvested by the $\mathrm{NaI}$ method was less than that of the protease $\mathrm{K}$ method (Figure 2). The reason for this might be that the iodide ion in NaI interfered with the ultraviolet absorption process. Therefore, the NaI method is not suitable for use with the magnetic microsphere extraction method.

\section{Optimal magnetic microsphere doses for extraction of genomic DNA from human blood}

Because heme derivatives and porphyrins in blood can influence the effect of PCR amplification, they should be removed before extraction of DNA. Therefore, ammonium chloride hemolysin, Triton-Tris- $\mathrm{HCl}$ solution, and deionized water were used to pretreat the various blood samples. The DNA yield and recovery rate were then analyzed.

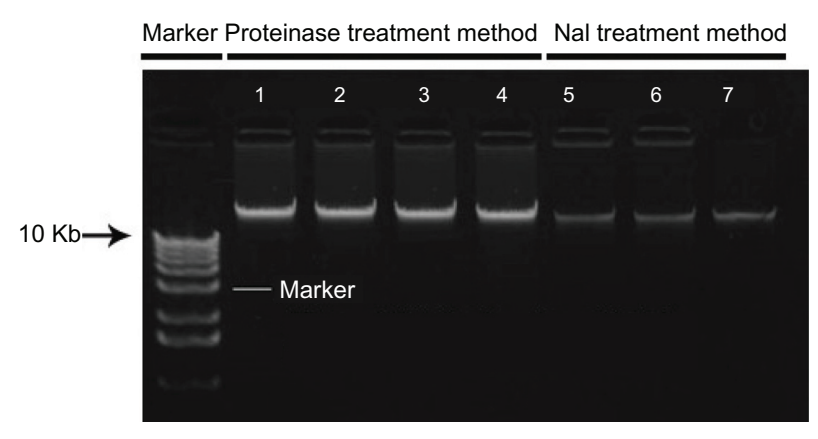

Figure 2 Comparison of genomic DNA obtained by the proteinase $\mathrm{K}$ method and the Nal method.

Notes: Various fresh blood samples were collected and genomic DNA was extracted by the proteinase treatment method (lanes I-4) and the Nal treatment method (lanes 5-7), respectively. The whole genomic DNA obtained was analyzed by agarose gel electrophoresis, and the results are shown. The nucleic acid molecular weight marker, I Kb DNA Marker II (NMWOI3), was from Beijing Dingguo Changsheng Biotechnology Co, Ltd (Beijing, People's Republic of China). 
Table 1 shows that both DNA yield and recovery rate were highest when the concentration of the magnetic suspension was $0.01 \mathrm{mg} / \mathrm{mL}$ and the total quantity used was $4 \mathrm{mg}$. The average amount of DNA extracted was $7.21 \pm 0.84 \mu \mathrm{g}$, which was significantly different from $1-3 \mathrm{mg}$ (control). The results of agarose gel electrophoresis (Figure 3) were not consistent with the DNA value measured by ultraviolet absorption, and the demonstrated qualities of seven different samples with 1-7 mg were basically fine (Figure 3 ).

Table 2 shows the results for extraction of human genomic DNA from the cell lysis mixtures using a magnetic suspension concentration of $0.01 \mathrm{mg} / \mathrm{mL}$, giving a total quantity of 1-8 mg. Both the recovery rate and yield of DNA increased with increasing doses of magnetic microspheres. It can be seen from the recovery experiment using calf thymus DNA that the magnetic microspheres adsorbed a lot of purified DNA. However, in the practical extraction application, only the right quantity of the magnetic microspheres could achieve a satisfactory yield and purity.

\section{Efficiency and purity of DNA extraction from fresh blood}

The results of ultraviolet absorption spectroscopy show a typical DNA absorption peak at $260 \mathrm{~nm}$ for the genomic DNA extracted by the magnetic suspension method (Figure 4).

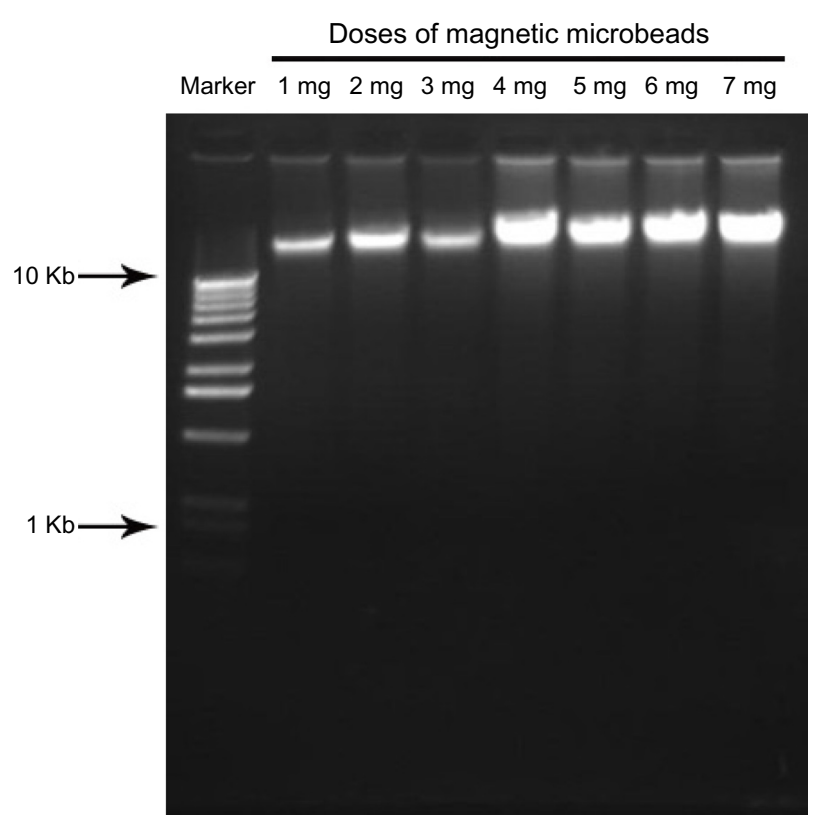

Figure 3 Agarose gel electrophoresis of genomic DNA extracted from fresh blood by using various doses of magnetic microbeads.

Notes: Blood samples were collected, and genomic DNA was extracted by the magnetic microbead method with different doses of magnetic microbeads ( $\mathrm{I}-7 \mathrm{mg}$ ). The whole genomic DNA obtained was analyzed by agarose gel electrophoresis, and the results are shown. Nucleic acid molecular weight marker, I Kb DNA Marker II (NMW0I3), was from Beijing Dingguo Changsheng Biotechnology Co, Ltd (Beijing, People's Republic of China).
Table 2 Genomic DNA from fresh blood extracted using various doses of magnetic microbeads

\begin{tabular}{llll}
\hline $\begin{array}{l}\text { 0.0I g/mL } \\
\text { magnetic } \\
\text { bead }(\mu \mathrm{L})\end{array}$ & $\begin{array}{l}\text { A260/A280 } \\
\text { ratio }\end{array}$ & $\begin{array}{l}\text { DNA content } \\
(\mu \mathrm{g} / \mathrm{mL})\end{array}$ & $\begin{array}{l}\text { Percent } \\
\text { recovery }(\%)\end{array}$ \\
\hline 100 & $1.786 \pm 0.265$ & $14.695 \pm 1.836$ & $36.738 \pm 4.590$ \\
200 & $1.888 \pm 0.316$ & $17.770 \pm 1.659$ & $44.425 \pm 4.148$ \\
300 & $1.871 \pm 0.268$ & $18.755 \pm 1.436$ & $46.887 \pm 3.590$ \\
400 & $1.856 \pm 0.353$ & $39.350 \pm 2.531$ & $98.375 \pm 0.328$ \\
500 & $1.839 \pm 0.485$ & $37.830 \pm 2.698$ & $94.575 \pm 1.745$ \\
600 & $1.810 \pm 0.358$ & $38.735 \pm 3.011$ & $96.838 \pm 1.528$ \\
700 & $1.828 \pm 0.367$ & $38.410 \pm 2.598$ & $96.025 \pm 1.495$ \\
\hline
\end{tabular}

Note: Values are \pm standard deviation.

\section{Agarose gel electrophoresis}

Agarose gel electrophoresis showed that the molecular weight of genomic DNA extracted by the magnetic suspension method was more than 10 kilobases with uniform brightness, suggesting that the extracted DNA was integrated and that the extraction effects were stable (Figure 5).

\section{PCR amplification in vitro}

The quality of the human genomic DNA extracted from whole blood was determined by PCR. The amplified PCR fragment was the housekeeping gene, $\beta$-actin, which has a relatively conserved gene sequence and constant expression

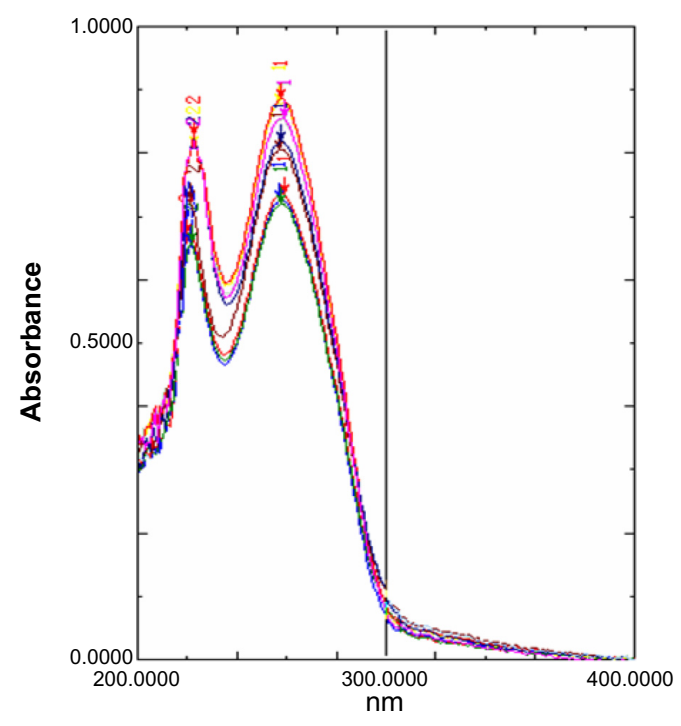

Figure 4 Ultraviolet absorption spectra for human genomic DNA obtained from fresh blood.

Notes: The extraction efficiency and purity of genomic DNA obtained from fresh blood by the magnetic microbead method was analyzed by ultraviolet absorption spectroscopy. There was an absorption peak at $260 \mathrm{~nm}$ for genomic DNA extracted by the magnetic microbead method, which is the typical DNA ultraviolet absorption peak. In terms of production, $7.21 \pm 0.84 \mu \mathrm{g}$ of genomic DNA $(n=30)$ was obtained from $200 \mu \mathrm{L}$ whole blood samples, which was significantly higher than that obtained by the conventional phenol chloroform method $(4.50 \pm 0.60 \mu \mathrm{g})$ and the high iodized salt method $(3.18 \pm 0.56 \mu \mathrm{g})$. Further, the yield of the magnetic microbead method was steady. The purity of DNA extracted by the magnetic microbead method was in the range of $1.81-1.92$, which is higher than that of the traditional method (1.65). 


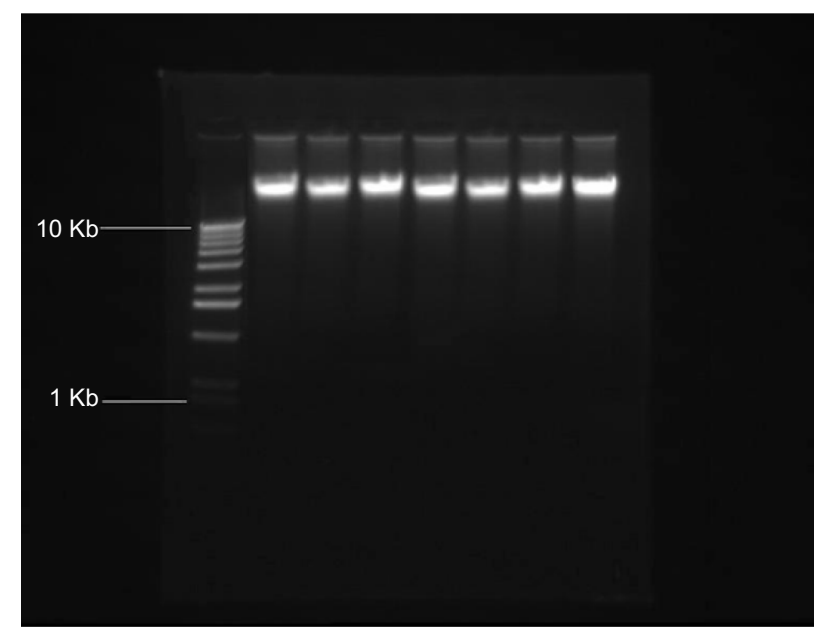

Figure 5 Agarose gel electrophoresis of genomic DNA obtained from fresh blood. Notes: Briefly, various fresh blood samples were collected and genomic DNA was extracted by the magnetic microbead method. The whole genomic DNA obtained was analyzed by agarose gel electrophoresis, and the results are shown. The data show that the molecular weight of the extracted DNA was greater than 10 kilobases and the brightness was uniform, indicating that the extracted DNA was complete, and the extraction effect by the magnetic microbead method is stable. Nucleic acid molecular weight marker, I Kb DNA Marker II (NMW0I3), was from Beijing Dingguo Changsheng Biotechnology Co, Ltd (Beijing, People's Republic of China).

levels under various conditions. As long as there is a relatively complete human genome DNA template, $\beta$-actin can be amplified. The genomic DNA copy number can be obtained indirectly by analyzing the copy number of the amplified $\beta$-actin. The $\beta$-actin copy number is closely related to the purity of the extracted genomic DNA. Essentially, if the purity of the extracted DNA is high, $\beta$-actin can be easily amplified. Gene amplification confirmed that the extracted genomic DNA was complete and its purity was high, indicating that it can be amplified effectively in vitro (Figure 6).

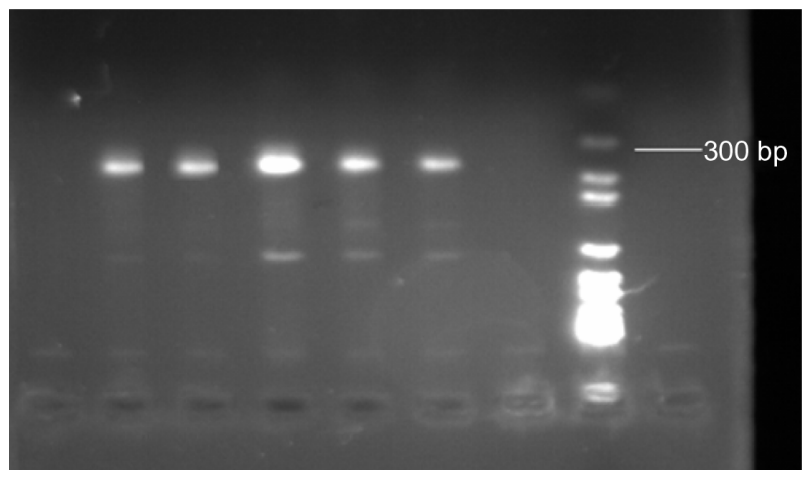

Figure 6 Agarose gel electrophoresis of PCR products with the genomic DNA extracted from fresh blood by the magnetic microbead method as the template. Notes: Various fresh blood samples were collected and genomic DNA was extracted by the magnetic microbead method. The whole genomic DNA obtained was used as the template for PCR analysis. The PCR products were subjected to agarose gel electrophoresis, and the results are shown. Nucleic acid molecular weight marker I Kb DNA Marker II (NMWOI3) was from Beijing Dingguo Changsheng Biotechnology Co, Ltd (Beijing, People's Republic of China).

Abbreviation: $\mathrm{PCR}$, polymerase chain reaction.

\section{Extracting genomic DNA from frozen blood using the magnetic microsphere method}

Ultraviolet absorption spectroscopy demonstrated that the concentration of genomic DNA extracted from $200 \mu \mathrm{L}$ of frozen blood by the magnetic microsphere method was $6.30 \pm 0.59 \mu \mathrm{g}(\mathrm{n}=30)$, while the concentration of genomic DNA extracted from the same frozen blood by the conventional method was only $2-3 \mu \mathrm{g}$. The purity of genomic DNA extracted by the magnetic microsphere method in the present study was in the range of 1.71-1.82, which is clearly superior to the value of 1.6 reported when using the traditional method.

The extracted genomic DNA samples were analyzed by gel electrophoresis. As shown in Figure 7, the molecular weight of the extracted genomic DNA was more than 10 kilobases, suggesting that the molecules of genomic DNA were extracted intact. The brightness of the extracted genomic DNA was uniform, indicating that the extraction efficiency was consistent across samples (Figure 7).

\section{Extracting genomic DNA from dried blood by magnetic microspheres}

Ultraviolet absorption spectroscopy demonstrated that the concentration of genomic DNA extracted from $200 \mu \mathrm{L}$ of dried blood by the magnetic microsphere method was $2.25 \pm 0.25 \mu \mathrm{g}(\mathrm{n}=10)$, and the purity was $1.58-1.66$. Trace blood ( $50 \mu \mathrm{L}$ and $100 \mu \mathrm{L}$ samples) could not be detected by ultraviolet absorption spectroscopy because the degree of dilution was out of range of the measurement method, so this should be detected by a more accurate method such as PCR analysis.

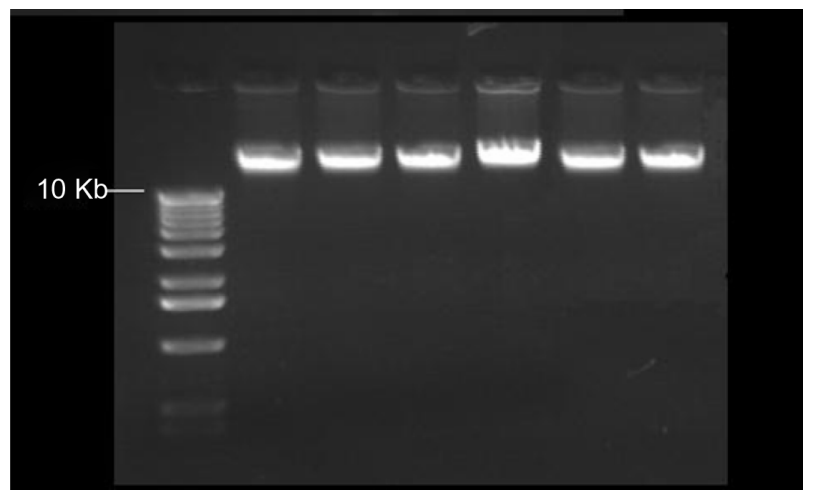

Figure 7 Agarose gel electrophoresis for genomic DNA extracted from dried blood.

Notes: Various dried blood samples were collected and genomic DNA was extracted by the magnetic microbead method. The whole genomic DNA obtained was analyzed by agarose gel electrophoresis, and the results are shown. The nucleic acid molecular weight marker, I Kb DNA Marker II (NMWOI3), was from Beijing Dingguo Changsheng Biotechnology Co, Ltd (Beijing, People's Republic of China). 
The gradient from trace amounts of DNA extracted from dried blood ( $50 \mu \mathrm{L}, 100 \mu \mathrm{L}, 200 \mu \mathrm{L})$ using the magnetic microsphere method was amplified in vitro. The amplified products were analyzed by agarose gel electrophoresis and compared with the molecular weight standard. The results show that the amplified fragment was of the expected size (Figure 8).

\section{Comparison of genomic DNA extracted by magnetic microspheres from different blood samples}

The genomic DNA content of fresh blood was high, whereas that extracted from frozen blood was low because DNA degradation had occurred and there was also loss of white cells. Further, large quantities of cells and their DNA content were lost from dried blood because of cell rupture and the grinding process, so the yield of DNA from dried blood decreased dramatically. Therefore, the state of a blood sample affects its DNA content to some degree. Other factors, including preservation time, also affect the yield and purity of DNA.

Fresh, frozen, and dried blood samples were used in this study, each at volume of $200 \mu \mathrm{L}$ as the micro blood standard. The yield and purity of DNA extracted from the three different types of blood samples are shown in Table 1. The yield of DNA from human blood varied according to the preservation conditions and blood states sampled. The amount of genomic DNA retrieved from frozen blood was not high because of the long freezing time and low temperature, along with loss of leukocytes. Dryness, loss of water, and grinding in the dried blood samples led to less DNA being available for retrieval by the extraction process.

\section{Discussion}

Magnetic microspheres are a new functional material that has been extensively studied in recent years, has been used in the biomedicine, bioengineering, and other fields of applied research, and has attracted research attention worldwide. For magnetic microspheres to be marketable, they need to have a uniform particle size, a strong magnetic response, good stability, and a surface rich in active functional groups. ${ }^{1-6}$ How to improve the binding efficiency and specificity of biological macromolecules on the surfaces of magnetic microspheres and expand their scope of application has been the focus of intense research interest.

The present study investigated the effects of adsorbent cell lysate composition and magnetic microsphere dose on the adsorption and recovery of DNA using actual blood samples and established operating procedures. Urea-formaldehyde resin was used as the solid phase carrier, and PEG and sodium chloride were used as the adsorbents. A human whole genomic DNA extraction procedure was established, in which
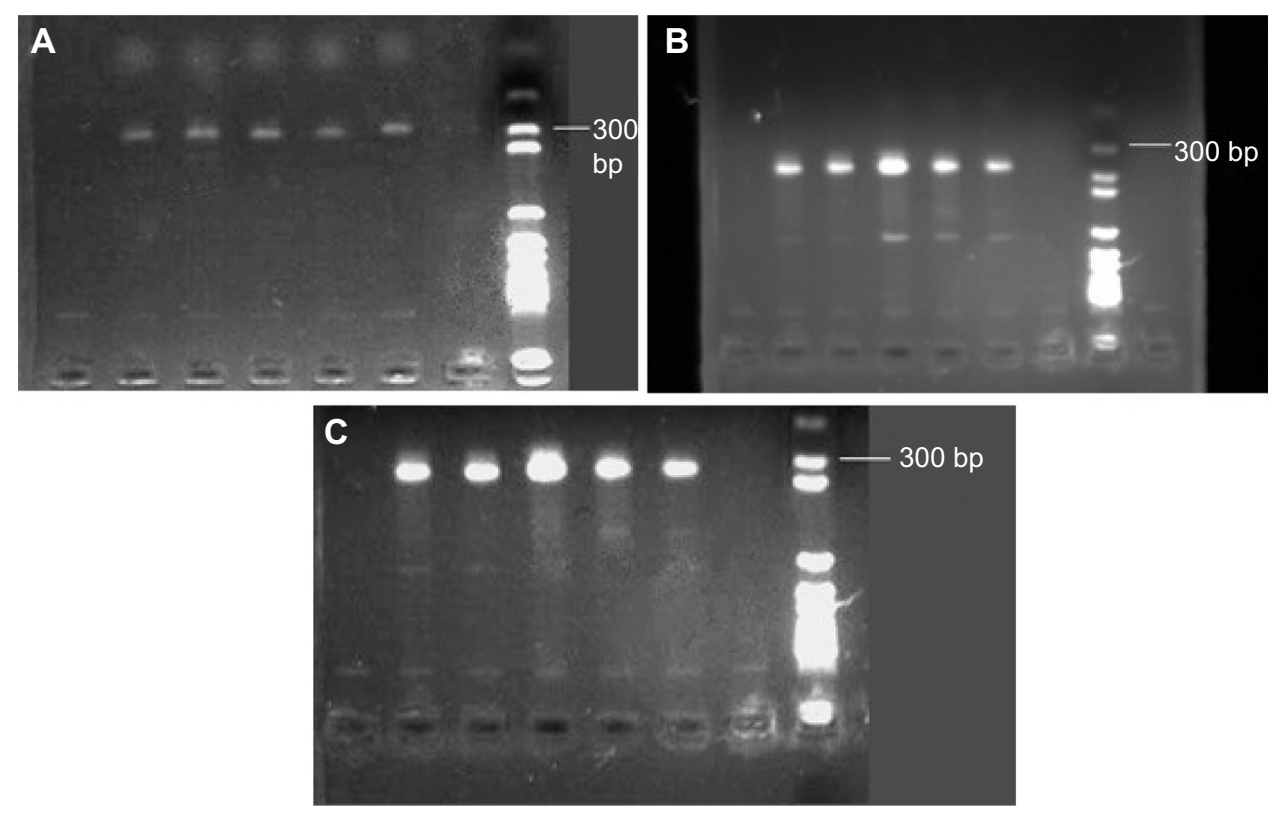

Figure 8 PCR results for genomic DNA extracted from dried blood. (A) $50 \mu \mathrm{L}$, (B) $100 \mu \mathrm{L}$, and (C) $200 \mu \mathrm{L}$.

Notes: Various dried blood samples were collected and genomic DNA was extracted by the magnetic microbead method. The whole genomic DNA obtained was used as the template for PCR analysis. The nucleic acid molecular weight marker, I Kb DNA Marker II (NMW0I3), was from Beijing Dingguo Changsheng Biotechnology Co, Ltd (Beijing, People's Republic of China).

Abbreviation: PCR, polymerase chain reaction. 
deionized water was used in the early stage of treatment and protease $\mathrm{K}$ digestion buffer was used to digest the proteins. We also studied the effects of different preservation conditions on the DNA content of blood samples, and their effects on the amount of DNA that could be extracted. We mainly used $200 \mu \mathrm{L}$ traces of fresh whole blood, cryopreserved blood, and dried blood to extract and purify genomic DNA. Ultraviolet spectroscopy was used for detection of DNA purity and content, the integrity of the extracted DNA was examined by agarose gel electrophoresis, and the DNA obtained was used as a template for PCR amplification. The phenol chloroform extraction method was also used to extract genomic DNA from the reference sample. The results show that the magnetic bead method was better than the conventional method.

The mechanism by which genomic DNA is extracted by the magnetic microspheres also warrants discussion. Urea-formaldehyde resin matrix magnetic microspheres specifically bind target genomic DNA in an external magnetic field using their surface affinity ligands, by affinity adsorption, washing, and elution. The novel urea-formaldehyde resin magnetic microspheres developed in the present study could also be used as part of multifunctional automatic magnetic separation equipment.

In addition, the innovative magnetic microsphere method using urea-formaldehyde resin as the matrix and adsorbent was improved in the present study to decrease hemochrome and protein contamination, which significantly improves the yield and purity of DNA, and the results obtained are better than those previously reported in the literature and for commercial kits.

The A260/A280 ratios of the genomic DNA extracted from fresh whole blood, frozen blood, and dry blood using the magnetic microsphere method were in the ranges of $1.81-1.92,1.71-1.82$, and 1.56-1.64, respectively. The average yields of DNA from $200 \mu \mathrm{L}$ of fresh whole blood, frozen blood, and dry blood were $7.21 \pm 0.84 \mu \mathrm{g}, 6.30 \pm 0.59 \mu \mathrm{g}$, and $2.15 \pm 0.25 \mu \mathrm{g}$, respectively. All genomic DNA extracted from the blood samples had the typical absorption peak for DNA by ultraviolet detection. The gel electrophoresis results showed that the DNA extracted had a high degree of intactness and could be used for efficient PCR analysis. The genomic DNA extracted from $50 \mu \mathrm{L}, 100 \mu \mathrm{L}$, and $200 \mu \mathrm{L}$ gradient ultratrace dried blood was used in the PCR amplification analysis with human-specific primers, and the results showed that the application effect was generally good.

Our experiments confirm that porous magnetic microspheres can be prepared by the template method. These microspheres have strong magnetic responses, a uniform particle size distribution, and a large specific surface area, which can be successfully used for the separation and purification of human whole blood genomic DNA. Being able to extract human blood genomic DNA with magnetic microspheres from blood preserved under different conditions has great advantages, in that the extracted genomic DNA is intact and of high quality, and can be used in molecular biology testing such as PCR. The biggest advantage of human whole blood genomic DNA extracted in this way is that it is efficient, convenient, fast, and automatic, although further investigations are necessary.

As early as 1979, DNA was purified using a glass method with NaI, which is efficient and rapid, and allows DNA of high quality to be obtained. Purified DNA obtained by this method can be used in restriction enzyme analysis and mapping experiments. ${ }^{12}$ Boom et $\mathrm{al}^{13}$ developed a rapid, reliable, and simple method for extraction of both RNA and DNA from human urine and serum on a small scale by using size-fractionated silica particles in 1990. The DNA extracted by Boom et al $^{13}$ could only be used efficiently as a substrate for restriction endonucleases and DNA ligase but not in PCR because it contained unknown components that prevented analysis. Another reason was that there was often contamination of trace doses of extracted DNA from contemporary samples, leading to unreliable results. ${ }^{13}$ The silica-based extraction method is mainly used for purification of DNA from ancient bone samples, has high extraction efficiency, and is also fast and simple to perform. Moreover, the quality of DNA extracted from such bone samples is good and meets the requirements for further analysis, especially PCR. ${ }^{14}$ Tanaka et $\mathrm{al}^{15}$ investigated the characteristics of DNA on aminosilane-treated magnetic nanoparticles, and efficient recovery of DNA was achieved for PCR.

The data indicate that protic and aprotic solvents play an important role in the purification of DNA obtained by magnetic nanoparticles. Further, DNA extracted by this method can be used in subsequent restriction enzyme digestion and PCR experiments, which are better than previous methods. ${ }^{15}$ Charge switch nucleic acid purification technology is an important method for DNA extraction, and is already commercialized as the nonorganic solvent extraction method. However, it is expensive and not efficient for extraction of human genomic DNA from fresh whole blood, frozen blood, dried blood, or trace blood.

The method used in our present study is superior to other published methods. First, the urea-formaldehyde resin matrix magnetic microspheres we prepared have a strong magnetic response, good stability, a uniform particle size distribution, 
and a large specific surface area. Second, they are more efficient in extracting human genomic DNA from frozen blood, dried blood, and trace blood, with different morphologies under different storage conditions by magnetic microsphere methods than traditional magnetic microsphere methods in previous studies. Third, the genomic DNA extracted by the magnetic microsphere method is intact and of high quality, and meets the requirements for PCR. Fourth, the cost of preparation of urea-formaldehyde resin matrix magnetic microsphere is lower than the costs detailed in previous studies. Fifth, the urea-formaldehyde resin matrix magnetic microsphere method can be used for high-throughput extraction of human blood genomic DNA.

Our study has some limitations. First, porous magnetic microspheres need to be prepared, which requires additional time and added expense. Second, it is necessary to explore and prepare magnetic microspheres with a stable structure, controllable granularity, high saturation magnetization, low nonspecific binding, a biocompatible superparamagnetic separation carrier to improve the coupling efficiency of surface groups, optimization of process conditions, reduction of cost, and realization of scale production in further research. Third, it is important to expand the field of application of the magnetic microsphere method to other biological separation protocols, such as virus-specific nucleic acid probe hybridization separation and separation of immune marker cells. Fourth, the magnetic microsphere method needs to be tested for its ability to extract DNA from different types of samples such as bone, tissue, hair, and contaminated tissues. ${ }^{16}$

\section{Conclusion}

A magnetic microsphere suspension was prepared and used to extract genomic DNA from fresh whole, frozen, dried, and trace blood. The results of this study build a good foundation for research and development of high-throughput and rapid extraction of genomic DNA from various types of blood samples.

\section{Acknowledgment}

This work was supported by a grant from the National Natural Science Foundation of China.

\section{Disclosure}

The authors report no conflicts of interest in this work.

\section{References}

1. Cho YK, Lee JG, Park JM, Lee BS, Lee Y, Ko C. One-step pathogen specific DNA extraction from whole blood on a centrifugal microfluidic device. Lab Chip. 2007;7:565-573.

2. Hansen WL, Bruggeman CA, Wolffs PF. Pre-analytical sample treatment and DNA extraction protocols for the detection of bacterial pathogens from whole blood. Methods Mol Biol. 2013;943:81-90.

3. Li J, Liu Q, Alsamarri H, Lounsbury JA, Haversitick DM, Landers JP. Label-free DNA quantification via a 'pipette, aggregate and blot' (PAB) approach with magnetic silica particles on filter paper. $L a b$ Chip. 2013;13:955-961.

4. Keeley B, Stark A, Pisanic TR 2nd, et al. Extraction and processing of circulating DNA from large sample volumes using methylation on beads for the detection of rare epigenetic events. Clin Chim Acta. 2013;425:169-175.

5. Ma C, Li C, Wang F, et al. Magnetic nanoparticles-based extraction and verification of nucleic acids from different sources. $J$ Biomed Nanotechnol. 2013;9:703-709.

6. Patramool S, Bernard E, Hamel R, et al. Isolation of infectious chikungunya virus and dengue virus using anionic polymer-coated magnetic beads. J Virol Methods. 2013;193:55-61.

7. He N, Wang F, Ma C, et al. Chemiluminescence analysis for HBV-DNA hybridization detection with magnetic nanoparticles based DNA extraction from positive whole blood samples. J Biomed Nanotechnol. 2013;9:267-273.

8. Shan Z, Zhou Z, Chen H, et al. PCR-ready human DNA extraction from urine samples using magnetic nanoparticles. $J$ Chromatogr B Analyt Technol Biomed Life Sci. 2012;881-882:63-68.

9. Duarte GR, Price CW, Littlewood JL, et al. Characterization of dynamic solid phase DNA extraction from blood with magnetically controlled silica beads. Analyst. 2010;135:531-537.

10. Zhang Y, Kuang M, Zhang L, Yang P, Lu H. An accessible protocol for solid-phase extraction of N-linked glycopeptides through reductive amination by amine-functionalized magnetic nanoparticles. Anal Chem. 2013;85:5535-5541.

11. Yuan Y, Zhang W, Yan R, et al. Identification of a novel 14-3-3zeta binding site within the cytoplasmic domain of platelet glycoprotein Ibalpha that plays a key role in regulating the von Willebrand factor binding function of glycoprotein Ib-IX. Circ Res. 2009;105:1177-1185.

12. Vogelstein B, Gillespie D. Preparative and analytical purification of DNA from agarose. Proc Natl Acad Sci U S A. 1979;76:615-619.

13. Boom R, Sol CJ, Salimans MM, Jansen CL, Wertheim-van Dillen PM, van der Noordaa J. Rapid and simple method for purification of nucleic acids. J Clin Microbiol. 1990;28:495-503.

14. Höss M, Pääbo S. DNA extraction from Pleistocene bones by a silicabased purification method. Nucleic Acids Res. 1993;21:3913-3914.

15. Tanaka T, Sakai R, Kobayashi R, Hatakeyama K, Matsunaga T. Contributions of phosphate to DNA adsorption/desorption behaviors on aminosilane-modified magnetic nanoparticles. Langmuir. 2009;25: 2956-2961.

16. Li G, Shen B, He N, Ma C, Elingarami S, Li Z. Synthesis and characterization of Fe3O4@SiO2 core-shell magnetic microspheres for extraction of genomic DNA from human whole blood. J Nanosci Nanotechnol. 2011;11:10295-10301. 
International Journal of Nanomedicine

Dovepress

\section{Publish your work in this journal}

The International Journal of Nanomedicine is an international, peerreviewed journal focusing on the application of nanotechnology in diagnostics, therapeutics, and drug delivery systems throughou the biomedical field. This journal is indexed on PubMed Central, MedLine, CAS, SciSearch ${ }^{\circledR}$, Current Contents ${ }^{\circledR} /$ Clinical Medicine,
Journal Citation Reports/Science Edition, EMBase, Scopus and the Elsevier Bibliographic databases. The manuscript management system is completely online and includes a very quick and fair peer-review system, which is all easy to use. Visit http://www.dovepress.com/ testimonials.php to read real quotes from published authors.

Submit your manuscript here: http://www.dovepress.com/international-journal-of-nanomedicine-journal 